\title{
Preliminary studies on pharmaceutical microencapsulation for synbiotic application
}

\section{S.E. Evivie}

Food Science and Technology Unit, Department of Animal Science, University of Benin, PMB 1154, Benin City, NIGERIA E-mail: smithyevivie@gmail.com

Received: 0 ctober 8, 2013; Revised received: November 14,2013; Accepted:December 5, 2013

Abstract: The solvent evaporation technique was used in this study to evaluate probiotics microencapsulation in AQOAT/ dichloromethane matrix and cell viability was also measured to assess its potentials in industrial food formulation processes. Cumulative release experiments using water blue dye as a model molecule was also used to evaluate the prebiotic applications. Well-defined spherical AQOAT microcapsules [50.0 ìm $\pm(24.14)]$ were formed from $5 \%$ AQOAT solution. Cells of Bifidobacterium breve and Lactobacillus plantarum were successfully encapsulated with this technique. However, a 7 log and a 5 log reduction were recorded for B. breve and L. plantarum respectively after $60 \mathrm{~min}$ in buffer $(\mathrm{P}<0.05)$. Results of this study showed that $1 \%$ AQOAT solution lowered viability by 1 log and cell exposure to $10 \mathrm{ml}$ dichloromethane resulted in a 3 log reduction, thus confirming bactericidal properties of both polymer and organic solvent. DCM was however shown to have more bactericidal effects on the cells $(P<0.001)$. Cumulative release trials using $0.2 \%$ water blue dye solution showed a $40 \%$ loss and encapsulation efficiency (EE) of $73.8 \%( \pm 14.76)$. It was recommended that viability counts using this technique be further evaluated using other organic solvents (such as ethyl acetate and chloroform) or other synthetic polymers so as to increase its applicability in the food industry.

Keywords: Cumulative release, Microencapsulation, Prebiotics, Probiotics, Viability

\section{INTRODUCTION}

The need to ensure healthy living through dietary practices is fast becoming an interesting area of investigation in the Food industry worldwide. These include the use of probiotics and prebiotics. Probiotics are live microorganisms which when ingested in adequate quantities confer one or more demonstrated health benefits for the host such as increasing immunity levels (Reid, 2001; Gill et al., 2001). These bacteria cells have been recommended in treating health disorders such as lactose intolerance, food allergies, diarrhea and colon cancer (Szajewska and Mukowicz, 2001; Kallomaki et al., 2003; Lee et al., 2003; Korugol and Koturogolu, 2005; Szajewska et al.,2006). Prebiotics are specifically fermented by certain probiotic bacteria and this has been shown to have therapeutic effects as well (Roberfroid, 2001; Moro et al.,2002; Ziegler et al., 2007).

The health-promoting properties of synbiotics (probiotics and prebiotics) have become an interesting and prospective area of research with immune effects attributed to modulation of the gut microflora of the host (Gismondo et al.,1999; Femia et al.,2002; Chakraborti, 2011; Liong, 2008). They have thus been used in some food formulations (Desmond et al., 2005). However, the ability of bacteria cells to survive and multiply in the intestine of the host is essential to them having an effect ISSN : 0974-9411 (Print), 2231-5209 (Online) All Rights Reserved @ Applied and Natural Science Foundation www.ansfoundation.org on the host. Microencapsulation is one of the techniques used to increase survival rates of sensitive microorganisms against a range of unfavorable external conditions in the host (Gismondo et al.,1999; Anal and Singh, 2007).

Microencapsulation involves packaging the probiotic microorganisms in a micron-range, closed capsule and enables the content therein to be released under specific conditions. This approach has been shown to release cells at sustained and continuous rates in therapeutic products (Murua et al.,2008). The use of polymer microcapsules as delivery systems has been reported and reviewed in recent literature to have desirable pharmaceutical applications (Paul et al., 2011; Prakash et al., 2011; Baffoni et al., 2012; Shaik et al., 2012). How flexible or rigid they are plays an important role their structure-function relationship as well as their scope of application in the food and biomedical industries (Morrisa et al., 2008). Some of the synthetic polymers (produced from suitable monomers) that can be used for encapsulation include polyesters, poly (ortho esters), polyanhydrides and polyphosphazenes (Park et al., 2005; Della Porta et al., 2012). The solvent evaporation technique is the most extensively used method of microencapsulation involving the formation of a doublelayer emulsion by vigorous stirring to remove the organic 
solvent, leaving solid microspheres. It has good process reproducibility preparations, requires less time and less operation skills (Tiwari and Verma, 2011). In this study, solvent evaporation technique will be used to encapsulate probiotic bacteria within an AQOAT shell which is insoluble at $\mathrm{pH}$ d" 6.8 .

The use of microencapsulation techniques in various food formulations has also been recognized. High success levels have been achieved in encapsulating various food ingredients like minerals, flavors and ascorbic acid. However, the microencapsulation of probiotics suggests that the technique needs further optimization as studies have shown varying successes over the years (Vidhyalakshmi et al.,2009). This technology has also been successful with inclusion of prebiotics in food products. Adding inulin through a double-microencapsulation technique was shown to increase the viability of Lactobacillus acidophilus in yoghurt (Ann et al.,2007).

In spite of the success of this technique in the food industry, some key challenges have been identified which require more thorough in vitro and in vivo investigations. These constraints range from further evaluation and optimization of the encapsulation process to investigating the stability and viability of the bacteria cells, whilst gaining a clearer understanding of the mechanisms of actions of the probiotics themselves. There is also the need to carry out more detailed studies to confirm the ability of microencapsulation techniques to deliver probiotic bacteria to their desired target while evaluating the controlled release aspects (Kaliasapathy, 2002; Prakash et al.,2011). It must be noted here that the tremendous successes reported confirm that probiotic and prebiotic microencapsulation will assume an important therapeutic role in the future.

Investigations by Della Porta et al. (2012) explored the use of solvent evaporation technique in producing poly lactic co-glycolic acid (PLGA) microcapsules with $L$. acidophilus as a model bacterium and recorded less than $5 \%$ viable cell count. The authors also emphasized that the technique had high applicability as it can be used to encapsulate genetically modified bacteria or dead cells to improve therapeutic efficiency. As $\mathrm{pH}$-dependent gelling agents, hydrophilic biodegradable polymers such as hydroxypropyl methylcellulose (HPMC) or AQOAT have been used in developing controlled release formulations. With a molecular weight of 18000 , this polymer is most noted for its characteristic high swelling ability which may be a property that can be explored (Sahoo et al.,2011). However, its use in encapsulating bacterial cells or prebiotics in the food industry is yet to be investigated.

The objectives of this study, therefore, are to evaluate the solvent evaporation technique as described by Della
Porta et al. (2012) using AQOAT/ dichloromethane as a model polymer and organic solvent respectively to assess its applicability to encapsulate probiotics and evaluate how the solvent preparation affects cell survival. Water blue dye solution (hydrophilic particle) will be included in the procedure to measure the encapsulation efficiency, level of loss on exposure to acidic solution and controlled release trials under simulated gastrointestinal tract conditions. This will be used to evaluate the potentials of this technique in encapsulating small-size prebiotics such as fructo-oligosaccharides (FOS) and galactooligosaccharides (GOS).

\section{MATERIALS AND METHODS}

$M$ aterials: AQOAT (AS-HF grade) was purchased from Shin Etsu Co. Ltd. UK and dichloromethane (DCM) was obtained from Sigma Aldrich Co. Ltd, France. The model bacteria strains used were L. plantarum (high resistance) and Bifidobacterium breve (high sensitivity). Strains were grown at $37{ }^{\circ} \mathrm{C}$ for $12 \mathrm{~h}$ and $22 \mathrm{~h}$ respectively in hunger tubes of $10 \mathrm{ml}$ tryptone peptone yeast (TPY) broth in an incubation chamber. The media used for this study were (Wilkins Chalgren agar for Bifidobacterium breve and MRS agar for L. plantarum) and phosphate buffer saline (PBS) solution at $\mathrm{pH}$ 7.2. Water blue dye (used as the small molecule model), gastric solution $(0.2 \% \mathrm{NaCl}$, $\mathrm{pH} 2.0$ ), The $\mathrm{pH}$ of solutions containing AQOAT microcapsules in acid exposure trials were adjusted using $2 \mathrm{M} \mathrm{HCl}$ and $1 \mathrm{M} \mathrm{NaOH}$ solutions

Experimental

Formulation of suitable polymer concentration: Preliminary tests were carried out to determine the appropriate concentration of AQOAT for microencapsulation. A known weight of AQOAT was dissolved in $10 \mathrm{ml}$ DCM for $24 \mathrm{~h}$. The primary emulsion was formed by adding $0.5 \mathrm{ml}$ of distilled water the dissolved polymer matrix in $10 \mathrm{ml}$ DCM and stirring at $1200 \mathrm{rpm}$ using an overhead stirrer. The secondary emulsion was formed by adding the primary emulsion to $1 \%$ sodium alginate solution (surfactant) and stirred at $1200 \mathrm{rpm}$ for $1 \mathrm{~h}$. The solution was centrifuged at 3000 rpm for 5 min to separate microcapsules from solvent. The supernatant was discarded and samples of microcapsules were viewed under a light microscope before and after freeze-drying for $22 \mathrm{~h}$.

Probiotic experiment

Biomass production: Viable cells of $L$. plantarum were obtained from a two-step process. Cells from a frozen culture (stored at $-80^{\circ} \mathrm{C}$ ) were streaked on Petri dishes containing MRS agar and left for $48 \mathrm{~h}$ to grow. Isolated colonies were inoculated into a $10 \mathrm{ml}$ TPY broth under anaerobic conditions and stored in an incubation chamber for $12 \mathrm{~h}$ to obtain maximum exponential growth. The starting optical density (OD) for this strain was 2.6. An 
aliquot was obtained from this tube and re-inoculated into a new TPY broth in the second propagation for $12 \mathrm{~h}$. This was done using the formula:

$\mathrm{C}_{1} \mathrm{~V}_{1}=\mathrm{C}_{2} \mathrm{~V}_{2}$

where $\mathrm{C}_{1}=$ measured $\mathrm{OD}$ from first hunger tube; $\mathrm{V}_{1}=$ volume of aliquot to be re-inoculated into the second TPY tube (il); $\mathrm{C}_{2}=$ initial concentration of cells $(0.1)$ which corresponds to an OD of 2.0, and $\mathrm{V}_{2}=$ volume of TPY in a new hunger tube $=10 \mathrm{ml}$

An optical density of 2.6 after growth was used for each experiment. Solution was centrifuged at $3200 \mathrm{rpm}$ for 10 mins at $4{ }^{\circ} \mathrm{C}$ and supernatant was discarded to obtain cells. For B. breve, isolated colonies were obtained $48 \mathrm{~h}$ after streaking and the first cell propagation phase was for $22 \mathrm{~h}$ in TPY to obtain maximum exponential growth. The optical density was measured and adjusted to 0.1 by re-inoculating an aliquot in a new $10 \mathrm{ml}$ TPY hunger tube. This was incubated at $37{ }^{\circ} \mathrm{C}$ for $22 \mathrm{~h}$ in an incubation chamber and the OD was checked afterwards. Cells were prepared afterwards as described for L. plantarum.

Emulsion preparation: A w/o/w emulsion was formed using solvent evaporation following the procedure of Della Porta et al. (2012). A 5\% AQOAT solution was prepared in DCM and stirred for $24 \mathrm{~h}$ for complete dissolution. A $0.5 \mathrm{ml}$ vortexed cell solution was added to the $5 \%$ AQOAT solution and stirred at $1200 \mathrm{rpm}$ for $1 \mathrm{~min}$ using an overhead stirrer to form the primary emulsion. The primary emulsion was then added to a $1 \%$ sodium alginate solution and stirred for $60 \mathrm{~min}$ using the overhead stirrer to form the secondary emulsion. The final solution was then centrifuged at $3000 \mathrm{rpm}$ for $5 \mathrm{~min}$ at $4{ }^{\circ} \mathrm{C}$ and the supernatant removed to obtain AQOAT microcapsules. Cell viability counts: The starting cell concentration was obtained by spreading $0.1 \mathrm{ml}$ of cell suspension (for $\mathrm{L}$. plantarum or B. breve) on agar-filled Petri dishes at $10^{7}$ and $10^{8}$ dilution factors. Each experiment was carried out in triplicate giving a total of 6 plates for the two dilution factors. After microencapsulation of bacterial cells, the AQOAT microcapsules were dissolved in $50 \mathrm{ml}$ PBS solution ( $\mathrm{pH}-7.2)$ to expose the cells. Various dilutions were made in dilution bottles containing PBS solution (10-2, 10-4, 10-6 and 10-7) to ensure easy counting of isolate colonies. An aliquot of $0.1 \mathrm{ml} \mathrm{L}$. plantarum cells was spread on Petri dishes containing MRS agar at 0, 30 and 60 min after incubation of the cells in PBS buffer. An equivalent volume of $B$. breve cells was spread on Wilkins Chalgren agar-filled Petri dishes with the same dilution factors for L. plantarum. Plates were stored in an anaerobic cabinet for $2 \mathrm{~d}$ and isolate cell colonies were counted afterwards.

Dye experiment: Water blue dye (obtained from Sigma Aldrich, UK) was used as a model molecule for small prebiotic compounds such as GOS and FOS to evaluate recovery after acid exposure and controlled release trials.
A volume of $0.5 \mathrm{ml}$ from freshly-prepared $0.2 \%$ dye solution was added to a 5\% AQOAT solution and stirred at $1200 \mathrm{rpm}$ for $2 \mathrm{~min}$ to form the primary emulsion. Secondary emulsion was formed by adding the primary emulsion to $1 \%$ sodium alginate solution and stirred for $60 \mathrm{~min}$ at $1200 \mathrm{rpm}$. Solution was centrifuged at $3000 \mathrm{rpm}$ for $5 \mathrm{~min}$ to obtain microcapsules. A volume of $50 \mathrm{ml}$ gastric solution $(0.2 \% \mathrm{NaCl}, \mathrm{pH} 2.0)$ was used to resuspend AQOAT microcapsules and samples were taken in $2 \mathrm{ml}$ vials at 0 and $60 \mathrm{~min}$ after incubation in a water bath at $37{ }^{\circ} \mathrm{C}$. Volume of gastric solution was kept constant throughout the procedure by replacing the aliquot withdrawn for UV analysis with an equal amount of gastric solution. Centrifugation was done at $3000 \mathrm{rpm}$ for $5 \mathrm{~min}$ and the supernatant removed. Microcapsules were re-suspended in $50 \mathrm{ml}$ buffer solution and samples collected at 15, 30, 45 and 60 min after dissolution. All samples were analyzed by measuring absorbance using a UV spectrophotometer at wavelength of $577 \mathrm{~nm}$. PBS solution was used as the blank for all trials. Standards were run in gastric and buffer solutions to measure $\mathrm{pH}$ sensitivity of the dye.

Statistical analysis: The results are presented as means \pm standard deviation. Cell viability with time was analyzed by linear regression. The anti-microbial effect of AQOAT and DCM on cell survival was compared by t-test. Statistical analyses were done with Genstat (Genstat ${ }^{\circledR}$ 13th Edition, VSN Intl. Ltd, UK).

\section{RESULTS}

Different sizes of microcapsules were obtained, each depending on the AQOAT concentration used for the formulation (Fig 1). Images viewed under a light microscope showed an increase in microcapsule size as the concentration increased. All concentrations however gave well-formed, spherical microcapsules. The scale bar for each image was $75 \mu \mathrm{m}$.

Table 1 shows results of preliminary tests carried out to determine a suitable polymer concentration for this study. The concentration ranged from $1 \%$ to $10 \%$. Quality of microcapsule formed slightly decreased with increasing polymer concentration. Microcapsules showed increased gelation and the $10 \%$ solution in particular showed high wastage of polymer.

Fig 2 shows viability counts ( $\left.\log \mathrm{cfu} \mathrm{ml}^{-1}\right)$ for the two strains of bacteria used in this study- L. plantarum and B. breve cells before encapsulation, $30 \mathrm{~min}$ and $60 \mathrm{~min}$ after incubation in buffer solution. Counts were significantly different ( $\mathrm{p} \hat{\mathrm{A}} 0.05$ ) after $30 \mathrm{~min}$ in buffer but no significant difference was observed after $60 \mathrm{~min}$ when all microcapsules had completely dissolved. Although final cell count were low, L. plantarum cells was shown to be more suitable for the procedure as a $5 \log$ cell reduction was recorded as against a $7 \log$ reduction for 
Table 1. Relationship between AQOAT concentration and microcapsule size.

\begin{tabular}{|c|c|c|c|}
\hline $\begin{array}{c}\text { AQOAT } \\
\text { concentration }(\%)\end{array}$ & M icrocapsule size $(\mu \mathrm{m})^{d}$ & $\begin{array}{c}\text { Gelling } \\
\text { properties }\end{array}$ & Remarks \\
\hline 1 & $21.3 \pm 4.57$ & Low & $\begin{array}{l}\text { Well-formed microcapsules, } \\
\text { minimal wastage of polymer but } \\
\text { too small for bacteria } \\
\text { encapsulation }\end{array}$ \\
\hline 3 & $33.8 \pm 8.11$ & Low & Same as above \\
\hline 5 & $50.0 \pm 24.14$ & Moderate & $\begin{array}{l}\text { Good size for bacteria } \\
\text { encapsulation with well-defined } \\
\text { microcapsules, minimal wastage } \\
\text { and }\end{array}$ \\
\hline 10 & $68.1 \pm 27.54$ & High & $\begin{array}{l}\text { Large-size, well-defined } \\
\text { microcapsules for bacteria } \\
\text { encapsulation but high wastage }\end{array}$ \\
\hline
\end{tabular}

\footnotetext{
${ }^{\mathrm{a}}$ Means are of three replicates each of five runs ( \pm standard deviation)
}

\section{$B$, breve strain.}

The effects of $1 \%$ AQOAT solution and $10 \mathrm{ml}$ DCM on B. breve cells were also investigated. The results show a 1 $\log$ cell reduction with $1 \%$ AQOAT solution after $60 \mathrm{~min}$ while a $3 \log$ reduction was recorded with DCM. Significant differences in cell concentration were observed after 60 min confirming that both organic solvent and model polymer had killing effects on probiotic cells with DCM having a higher impact.

In vitro results showed that $73.8 \%( \pm 14.76)$ dye solution (small molecule model) was successfully encapsulated and released after $60 \mathrm{~min}$ of microcapsule dissolution in buffer (Fig 4). Minimum encapsulation efficiency (EE) value shows that $59.1 \%$ of the dye was retained by the microcapsules during the $60 \mathrm{~min}$ incubation period in gastric solution $(0.2 \% \mathrm{NaCl}, \mathrm{pH} 2.0)$ and released over a $60 \mathrm{~min}$ period when microcapsules were dissolved in buffer solution. This is equivalent to a maximum dye loss of $40.9 \%$.

\section{DISCUSSION}

Preliminary test results: microcapsule size and mor phology: Preliminary tests for microcapsule formation were successful giving a mean size of $50.0 \mu \mathrm{m}( \pm 24.14)$ with a 5\% AQOAT solution. Light microscope images showed spherical microcapsules with smooth outer surfaces (Fig 1). This was observed to be consistent for all the trial concentrations prepared in this study $(1,3,5$ and $10 \%$ ). Sizes of microcapsules were observed to increase with increasing AQOAT concentration. The largest sizes were formed from a 10\% AQOAT solution $(68.1 \mu \mathrm{m} \pm 27.54)$ which is favorable for probiotic and prebiotic microencapsulation. This was the highest AQOAT concentration formed due to gelling problems. High wastage of polymer and DCM was also observed as AQOAT dissolution took a longer time and more DCM was required for each trial. This could be due to the highly viscous nature of AQOAT as it has been reported to have a characteristic swelling ability (Sahoo et al.,2011). Microcapsule sizes ranged from $21.3 \mu \mathrm{m} \pm 4.57(1 \%$ AQOAT solution) to $68.1 \mu \mathrm{m} \pm 27.54$ (10\% AQOAT solution) thus indicating a positive correlation between polymer concentration and microcapsule size (Table 1). This means that as the AQOAT concentration was increased, so did the sizes of the resultant microcapsules. However, the resulting solutions become more viscous and eventually gel at the $10 \%$ concentration. The size of microcapsules to be used depends on its intended use (Heidebach, et al.,2010) and the parameters for the formulation in this study were low wastage, less gelling and size of at least $50 \mu \mathrm{m}$ for encapsulation of the bacterial cells. There was a strong positive linear relationship $\left(R^{2}\right.$ $=0.95$ ) between AQOAT concentration and microcapsule size. The equation for the relationship is given as:

Microcapsule size $=18.7( \pm 2.98)+5.2( \pm 0.54) *$ AQOAT concentration

The $5 \%$ concentration was chosen for this study because of large microcapsule size $(50 \mu \mathrm{m})$ compared to lower concentrations ( 3 and $1 \%$ ), well-formed microcapsules and minimal wastage compared to a $10 \%$ AQOAT solution, (Table 1). Particle size and microcapsule microstructure have been reported to vary with the biopolymer used as wall material (Pedroza-Islas et al.,1999)(a)

Probiotic experiments

Cell viability counts: Cell survival of $L$. plantarum and $B$. breve decreased $(P<0.001)$ linearly $\left(R^{2}=0.61\right)$ with time (Figure 2). The equation of the relationship is given by: Cell viability $=1.41 \exp ^{10}\left( \pm 9.83 \exp ^{8}\right)+\left(-2.83 \exp ^{8} \pm 2.53 \exp ^{7}\right)$ * time, with viability in cfu $\mathrm{ml}^{-1}$ and time defined in min. Although, t-test of the null hypothesis that mean cell survival at 60 mins of $B$. breve was equal to that of $L$. 

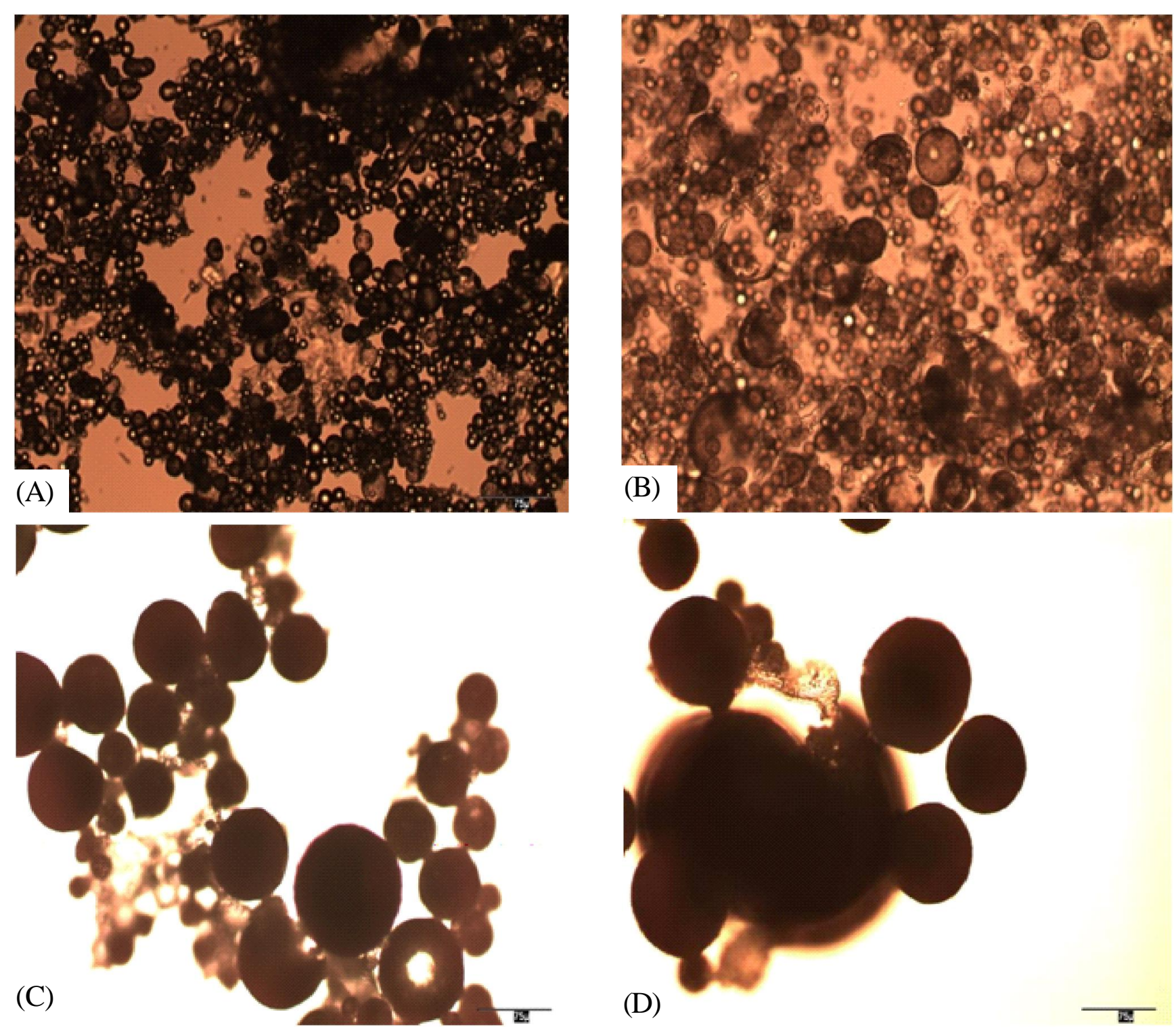

Fig. 1. I mages of microcapsul e morphologies from different AQ OAT concentrations (a) $1 \%$ (b) $3 \%$ (c) $5 \%$ and (d) $10 \%$.

plantarum was accepted $(P=0.359)$, cell survival of $B$. breve was lower $(P<0.001)$ at 30 min compared to $L$. plantarum at the same time (Fig 2).

Cells of both strains were successfully encapsulated using solvent evaporation technique. Average plate counts for B. breve before encapsulation and after encapsulation (30 and $60 \mathrm{~min}$ in buffer) were $1.01 \times 10^{10}$, $4.06 \times 10^{3}$ and $2.14 \times 10^{3} \mathrm{cfu} \mathrm{ml}^{-1}$ respectively. This implies a $7 \log$ reduction or $0.00001 \%$ cell survival. B. breve is a more sensitive gram positive bacteria strain than $I$. plantarum and this may have been responsible for lower cell viability counts. Further investigations are however required to confirm this as studies on strain-specificity levels may increase its applicability for future uses in the food industry. Average cell concentration before and after encapsulation (30 min and $60 \mathrm{~min}$ in buffer) were $1.02 \mathrm{X}$ $10^{10} \mathrm{cfu} \mathrm{ml}^{-1}, 6.78 \times 10^{7} \mathrm{cfu} \mathrm{ml}^{-1}$ and $3.12 \times 10^{5} \mathrm{cfu} \mathrm{ml}^{-1}$ respectively. This implies a $3 \log$ cell and $5 \log$ cell reductions after 30 min and 60 min respectively in buffer. These findings compare favorably with recent studies that the concentration of probiotic bacteria in food products should be at least $10^{6}$ to $10^{7} \mathrm{cfu}^{-1}$ prior to consumption (Nualkaekul et al.,2012). Solvent evaporation technique may thus be recommended as suitable for encapsulating probiotic bacteria such as $L$. plantarum for use in fermented food products as well as other formulations. The viability counts of $L$. plantarum and $\mathrm{B}$. breve can also be increased by optimizing the solvent evaporation technique. Optimization might be carried out by replacing the organic solvent used in this study with others, such as chloroform or ethyl acetate, adjusting the stirring speed to control shearing rate during encapsulation or re-suspending bacteria cells with other agents other than the supernatant after centrifugation and before encapsulation.

The results of this study agree with the findings of Della 

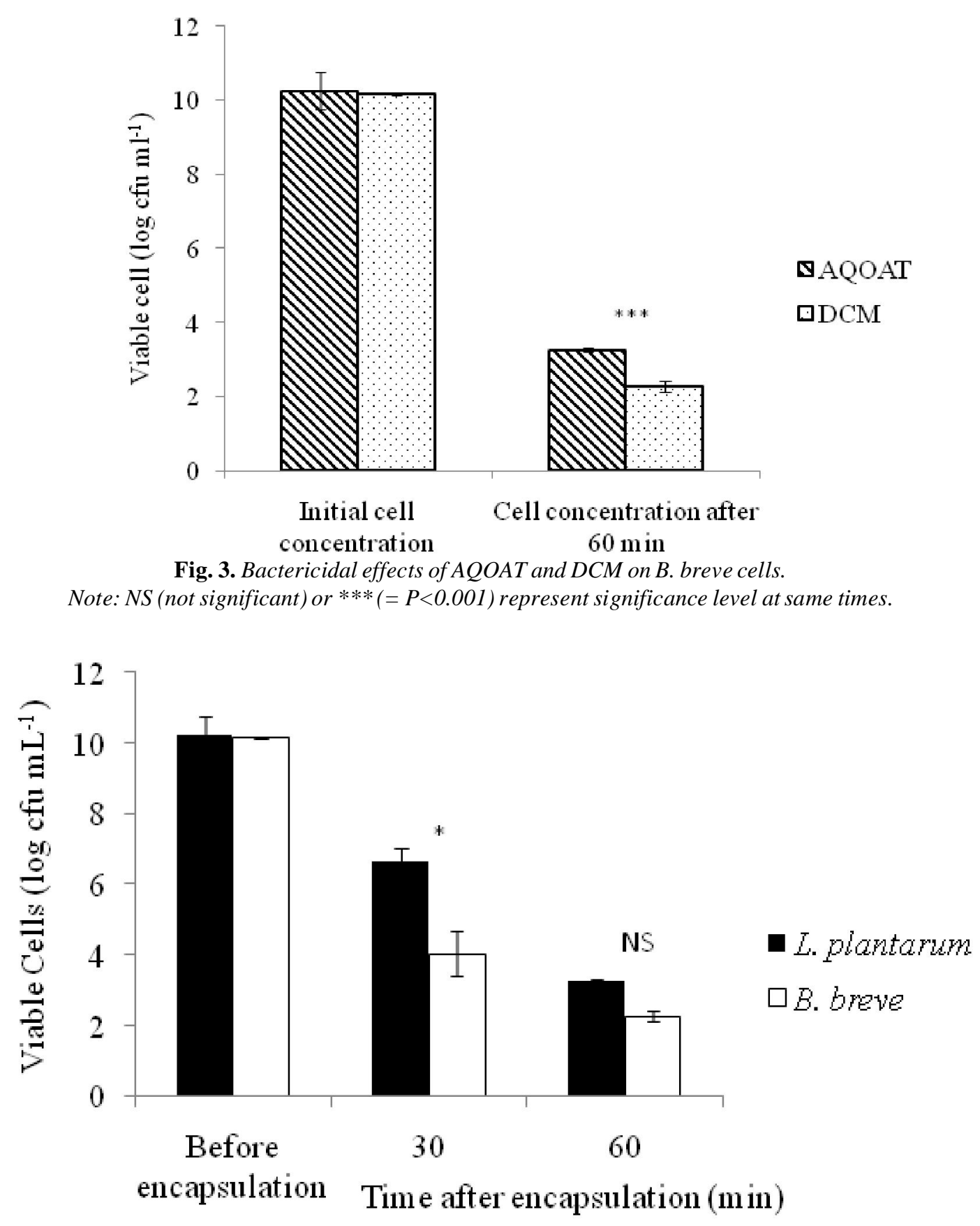

Fig. 2. Viability counts for $L$. plantarum and B. breve cells Note: NS (not significant) or * $(=\mathrm{P}<0.05)$ represent significance level at same times.

Porta et al. (2012) that cell viability was Â 5\% but in addition gives more specific details regarding viable cell counts and possible factors that may have lowered it. However, Della Porta et al. (2012) stated that the PLGA microcapsules were dissolved in an MRS broth for $36 \mathrm{~h}$ to release the cells for viability counts. This may have contributed to low viability as a previous study showed that PLGA microcapsule dissolution takes a longer time to occur (Graves et al.,2004). It was also observed in Della Porta's publication that the conclusion of less than $5 \%$ viability was not specific as this may mean bacteria cell counts from anywhere between $10^{2}$ to $10^{8} \mathrm{cfu} \mathrm{g}^{-1}$. The current study gives specific detail in this regard to further corroborate the conclusion of $\hat{A} 5 \%$ viability by Della Porta et al. (2012); 7- and 5-log cell reduction in B. breve and $L$. plantarum respectively after $60 \mathrm{~min}$ of microcapsule dissolution in buffer.

Test for cell killing effects of A Q OAT and DCM : Average viability counts for $B$. breve cells at the start of experiment and after $60 \mathrm{~min}$ in $1 \%$ AQOAT solution were $1.36 \times 10^{10}$ cfu ml ${ }^{-1}$ and $6.19 \times 10^{9} \mathrm{cfu} \mathrm{ml}^{-1}$ respectively, resulting in a $1 \log$ reduction (Fig 3). This suggests that AQOAT has some killing effects on cells as well as other poor enteric properties. Comparisons using t-test however showed 


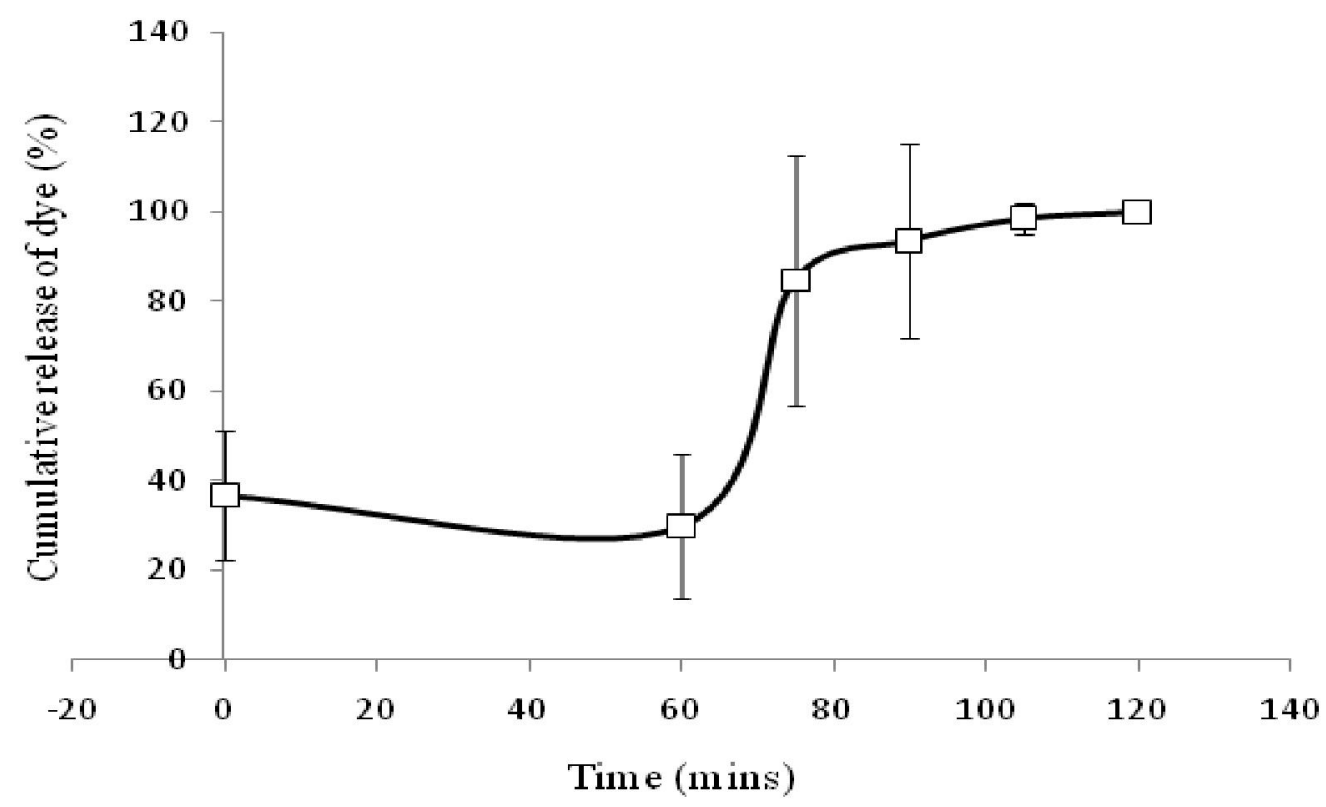

Fig. 4. Acid exposure and controlled-release profile of encapsulated water blue dye

no significant effects of AQOAT and DCM on initial cell concentration. Results also showed significant effects of DCM on viability of B. breve cells after $60 \mathrm{~min}$. Average cell counts before and after microencapsulation were 1.44 $\mathrm{X} 10^{10}$ and $1.33 \times 10^{7} \mathrm{cfu} \mathrm{ml}^{-1}$ respectively, indicating a 3$\log$ reduction $(0.1 \%$ cell survival). Comparison by t-test showed greater effects (PÂ0.0001) of DCM on viability than AQOAT. This finding suggests that the nature of polymer and organic solvent used are important parameters in evaluating the applicability of solvent evaporation technique in cell microencapsulation and viability. Other solvents which are volatile and immiscible with water (e.g ethyl acetate and chloroform) can be used in future studies to evaluate cell recovery using this technique.

The results of this study agree with the findings of Della Porta et al. (2012) that cell viability was Â $5 \%$ but in addition gives more specific details regarding viable cell counts and possible factors that may have lowered it. However, they stated that the PLGA microcapsules were dissolved in an MRS broth for $36 \mathrm{~h}$ to release the cells for viability counts. This may have contributed to low viability as a previous study showed that PLGA microcapsule dissolution takes a longer time to occur (Graves et al.,2004). It was also observed in Della Porta's publication that the conclusion of less than $5 \%$ viability was not specific as this may mean bacteria cell counts from anywhere between $10^{2}$ to $10^{8} \mathrm{cfu} \mathrm{g}^{-1}$. The current study gives specific detail in this regard to further corroborate the conclusion of Â $5 \%$ viability by Della Porta et al. (2012); 7- and 5-log cell reduction in B. breve and L. plantarum respectively after $60 \mathrm{~min}$ of microcapsule dissolution in buffer.

Cumulative release experiment using water blue dye:
The successful encapsulation of this small model molecule and its release rate into the small intestine strongly suggests the potential protective effects of this technique on prebiotics such as fructo-oligosaccharides (FOS) and galacto-oligosaccharides (GOS). The loss of color intensity of water blue dye in buffer with increasing time is suggestive of $\mathrm{pH}$-sensitivity. The dye appears most stable and retains its color at lower $\mathrm{pH}$ values as lower absorbance readings were observed from dye solution in buffer compared to dye molecules in gastric solution ( $\mathrm{pH} 2.0$ ).

Results from dye encapsulation experiments showed minimal dye loss in $1 \%$ alginate solution. This may be due to interactions between the hydrophobic ends of the dye and alginate solution during emulsification and centrifugation. The use of hydrophobic fluorescent dyes coated in thin PLGA films in formulating hydrophobic drug compounds has been reported (Steele et al.,2011). The authors showed that all fluorescent dyes successfully encapsulated in PLGA and released at desirable rates. Alginate has been successfully used in the food and beverage industry as a gelling agent and a colloid stabilizer (Brunetti, 2006). Cell viability evaluation results from the probiotic bacteria models used in this study also confirm that alginate had no killing effects on cells thus suggesting its use as an ideal surfactant in various food formulations. Its use as s surfactant in future studies involving bacteria cell and prebiotic encapsulation is thus recommended.

The use of PLGA microcapsules in Della Porta et al. (2012) was not tested for controlled release trials using prebiotic models. This may be so because PLGA polymer is non$\mathrm{pH}$ and non-temperature responsive and is thus likely to have longer release times in the gastrointestinal tract of 
the host (Graves et al.,2004). The need to evaluate the hydrophobicity of the polymer has also been recommended to improve its short-term and long-term release potentials (Makadia and Siegel, 2011). In this study, data from dye experiments strongly suggests that the solvent evaporation technique may be used to successfully encapsulate and release prebiotic materials at desired controlled rates into the small intestine where they are selectively fermented for the proliferation of beneficial gram positive bacteria strains.

Results from this study have shown that the use of probiotics and prebiotics prepared using solvent evaporation technique have the potentials to create a variety of products in the food industry that can be used for therapeutic purposes, thus confirming recent reports (Baffoni et al.,2012; Prakash et al.,2011; Shaik et al.,2012). The synergistic effects of both probiotics and prebiotics have the propensity to deliver delicate food ingredients to target cells in both humans and animals. These strains of bacteria can be used in the formulation of diverse functional foods appealing to different age groups of the population. Further studies are therefore required to optimize microcapsule size, choice of organic solvent and shearing rate among other parameters to increase the applicability of this symbiotic combination.

\section{Conclusion}

Microencapsulation is an important tool by which probiotics and prebiotics are protected and conveyed to target sites. This study showed that bacteria cells were successfully encapsulated using solvent evaporation technique but low viability was observed after $60 \mathrm{~min}$ in buffer. Viability counts were more specific on how low the counts were. Both AQOAT and DCM were shown to lower cell viability with increasing time, DCM having a more significant effect. Higher cell viability of $L$. plantarum over B. breve suggests that it may be a strainspecific procedure and can be optimized by using a suitable organic solvent (such as chloroform or ethyl acetate). The use of alginate as a surfactant was shown to have no significant side effects on cell viability and dye recovery trials. Results from dye encapsulation experiments showed that $60 \%$ of dye can be successfully encapsulated with a $40 \%$ loss after $60 \mathrm{~min}$ in gastric solution. It is however recommended that the technique be further optimized to enhance cell viability and also that further studies on polymer loading, acid degradation and controlled release be carried out to evaluate the protective potentials of this technique on prebiotics such as fructo-oligosaccharides (FOS), galactooligosaccharides (GOS) and inulin.

\section{ACKNOWLEDGEMENTS}

The Delta State Government and Education Trust Fund of Nigeria are thanked for support to S.E. Evivie. Samuel
Bizley and Joao de Barros, of the Department of Chemistry, University of Reading are appreciated for technical support.

\section{REFERENCES}

Anal A.K and Singh, H. (2007). Recent advances in microencapsulation of probiotics for industrial applications and targeted delivery - a review. Trends in Food Sci. and Technol., 18:240-251.

Ann, E.Y., Kim, Y Oh., S., Imm, J.Y., Park, D.J., Han, K.S. and Kim, S.H. (2007). Microencapsulation of Lactobacillus acidophilus ATCC 43121 with prebiotic substrates using a hybridization system. Int. J . Food Sci. and Technol., 42:411419.

Baffoni, L, Gaggia, F, Di Gloria, D, Satni, C, Mogna, L and Biawati, B (2012). A baifdobacterium-based symbiotic product to reduce the transmission of $C$.jejenum along the poultry food chain. Int. J . Food M icrobiol. 157(2):156-161.

Brunetti, M. (2006). Alginate polymers for drug delivery. A Bachelor of Science project report submitted to the Worchester Polytechnic Institute, United Kingdom.

Chakraborti, C.K. (2011). The status of synbiotics in colorectal cancer. Life Sci and M ed. Res., 20:1-15.

Della Porta. G., Castaldo, F., Scognamiglio, M., Paciello, L., Parascandola, P. and Reverchon, E. (2012). Bacteria microencapsulation in PLGA microdevices by superficial emulsion extraction. J. Sup. Fluids, 63:1-7.

Desmond, C.B., Corcoran, M., Coakley, M., Fitzgerald, G.F., Ross, R.P. and Stanton, C. (2005). Development of dairybased functional foods containing probiotics, and prebiotics. Austr. J. D airy Technol., 60:121-126.

Femia, A.P., Luceri, C., Dolara, P., Giannini, A., Biggeri, A., Salvadori, M., Clune, Y., Collins, K.J., Paglierani, M. and Caderni, G. (2002). Antitumorigenic activity of the prebiotic inulin enriched with oligofructose in combination with the probiotics Lactobacillus rhamnosus and Bifidobacterium lactis on azoxymethaneinduced colon carcinogenesis in rats. Carcino, 23:1953-1960.

Gill, H.S., Cross, M.L., Rutherfurd, K.J. and Gopal, P.K. (2001). Dietary probiotic supplementation to enhance cellular immunity in the elderly. British J . Biomed. Sci., 58:9496.

Gismondo, M.R., Drago, L. and Lombardi, A. (1999). Review of probiotics available to modify gastrointestinal flora. Int J. Antimicrob. Agents, 12:287-292.

Graves, R.A., Pamjula, S., Moiseyev, R., Freeman, T. Bostanian, A.L. and Mandal, T.K. (2004). Effect of different ratios of high and low molecular weight PLGA blend on the characteristics of pentamidine microcapsules. Int. J . Pharm., 270:251-262.

Heidebach, T., Forst, P. and Kulozik, U. (2010). Influence of casein-based microencapsulation in freeze-drying and storage of probiotic cells. J . F ood Eng., 98:309-316.

Kailasapathy, K. (2002). Microencapsulation of probiotic bacteria: technology and potential application. Curr. Iss. Intest. Microbiol., 3:39-48.

Kalliomaki, M., Salminen, S., Poussa, T., Arvilommi, H. and Isolauri, E. (2003). Probiotics and prevention of atopic disease: 4-year follow-up of a randomised placebo-controlled trial. Lanc., 361:1869-1871. 
Kurugol, Z. and Koturogolu, G. (2005). Effects of Saccharomyces boulardii in children with acute diarrhea, Acta Ped., 94:44 - 47.

Lee,Y.K., Puong, K.Y., Ouwehand, A.C. and Salminen, S. (2003). Displacement of bacterial pathogens from mucus and $\mathrm{CaCO}_{2}$ cell surface by Lactobacilli. J. Med. M icrobiol. 52:925-930.

Liong, M.T. (2008). Roles of probiotics and prebiotics in colon cancer prevention: postulated mechanisms and in-vivo evidence. Int. J. M ol. Sci., 9:854-863.

Makadia, H.K. and Siegel, S.J. (2011). Poly lactic Co-Glycolic acid (PLGA) as biodegradable controlled drug delivery carrier. Poly., 3:1377-1397.

Moro, G., Minoli, I. and Mosca, M. (2002). Dosage-related bifidogenic effects of galacto- and fructo-oligosaccharides in formula fed infants. J. Ped. G astro. Nutr., 34:291-295.

Morrisa, G.A., Torreb, J.G., Ortegab, A., Castilec, J., Smith, A. and Hardinga, S.E. (2008). Molecular flexibility of citrus pectins by combined sedimentation and viscosity analysis. Food H ydro., 22:1435-1442.

Murua, A., Portero, A., Orive, G., Hernández, R.M., de Castro, M. and Pedraz, J.L. (2008). Cell microencapsulation technology: toward clinical application, J. Contr. Rel., 132:76-83.

Nualkaekul, S., Lenton, D., Cook M.T., Khutoryanskiy, V.V. and Charalampopoulos, D. (2012). Chitosan coated alginate beads for the survival of microencapsulated Lactobacillus plantarum in pomegranate juice. C arb. Poly., 90:1281-1287.

Park, J.H., Ye, M. and Park, K. (2005). Biodegradable polymers for microencapsulation of drugs. M ol., 10:146-161.

Paul, A., Cantor, A., Shum-Tim, D. and Prakash, S. (2011). Superior cell delivery features of genipin crosslinked polymeric microcapsules: preparation, in vitro characterization and pro-angiogenic applications using human adipose stem cells. M ol. Biotechnol., 48(2):116-127.

Prakash, S., Tomato-Duchesneau, C., Saha, S. and Cantor, A. (2011). The gut microbiota and human health with emphasis on the use of microencapsulated bacterial cells: a review. J . Biomed. Biotechnol., doi:10.1155/2011/981214.

Pedroza-Islas, R., Vernon-Carter, E.J., Duran-Dominugez, C. and Terjo-Martinez, S. (1999). Using biopolymer blends for shrimp feedstuff microencapsulation - I. Microcapsule particle size, morphology and microstructure. Food Res. Int., 32:367-374.

Reid, G. (2001).Regulatory and clinical aspects of dairy probiotics. In Expert C onsultations on $\mathrm{H}$ eal th and $\mathrm{N}$ utritional Properties of Probiotics in F ood including P owder M ilk with Live Lactic Acid Bacteria., 15pg (FAO/WHO Background Report). Last assessed from ftp://ftp.fao.org/es/esn/food/ reid.pdf on September 09, 2012.

Roberfroid, M.B. (2001). Prebiotics: Preferential substrates for specific germs? Am. J . C lin. N utr., 73:S406-S409.

Sahoo, S., Chakraborti, C.K., Mishra, K.C. and Naik, S. (2011). Analytical characterization of a gelling biodegradable polymer. Drug Inv., 3:78-82.

Shaik, M.R., Kopsapati, M. and Panati, D. (2012). Polymers in controlled drug delivery systems. Int. J. Pharm. Sci., 2(4):112-116.

Steele, T.W.J., Huang, C.L., Kumar, S., Widjaja, E., Loo, J.S.C. and Venkatraman, S.S. (2011). High throughput screening of PLGA thin films utilizing hydrophobic fluorescent dyes for hydrophobic drug compounds. J. Pharm. Sci., 100:43174329.

Szajewska, H., Setty M. and Mrukowica, J. (2006). Probiotics in gastrointestinal diseases in children: Hard and not-so-hard evidence of efficacy. J. Ped. G astro. N utr., 42: 454-475.

Szajewska, H. and Mrukowicz, J. (2001) Probiotics in the treatment and prevention of acute infectious diarrhea in infants and children: A systematic review of published randomized, double blind, placebo controlled trials. J . Ped. Gastro. Nutr., 33:S17-S25.

Tiwari, S. and Verma, P. (2011). Microencapsulation techniques by solvent evaporation method (study of effects of process variables): a review. Int. J. Pharm. Life Sci., 2:998-1005.

Vidhyalakshmi, R., Bhakyaraj, R. and Subhasree, R.S. (2009). Encapsulation "the future of probiotics", a review. Adv. Biol. Res., 3:96-103.

Ziegler, E., Vanderhoof, J.A. and Petshow, B. (2007). Term infants fed formula supplemented with selected blends of prebiotics grow normally and have soft stools similar to those reported for breast fed infants. J. Ped. Gastro. Nutr., 44:359-364. 